\title{
Eastern and Western Woman Warriors: Through the Analyses of "The Woman Warrior" by Maxine Hong Kingston and "The Ginger Tree" by Oswald Wynd
}

\author{
Parvin Mursalova ${ }^{1}$ \\ ${ }^{1}$ The Department of Literature of Foreign Countries, Azerbaijan University of Languages, Baku, Azerbaijan \\ Correspondence: Parvin Mursalova, The Department of Literature of Foreign Countries, Azerbaijan University \\ of Languages, Baku, Azerbaijan. E-mail: genius83now@yahoo.com
}

Received: April 25, 2017 Accepted: May 24, 2017 Online Published: July 29, 2017

doi:10.5539/ijel.v7n5p220 URL: http://doi.org/10.5539/ijel.v7n5p220

\begin{abstract}
This article aims to scrutinize identity problem, through utilizing gender, cultural approaches and analyzing mother-daughter relationship. The distinctive attitudes of eastern and western societies towards woman identity bear undeniable differences, yet the existence of noticeable similarities cannot be rejected. East and West are regarded as two opposite poles; apparently modern discourse searches ultimate perspectives to investigate crossroads between these two opposite sites. Indeed, culture plays a significant part in detecting these perspectives. In this article the author makes an effort to analyze the prior cultural facets by employing literary analyses. Moreover, one of the problems that modern literary study is concerned with is mother-daughter relationship. The selected two literary works presented by this article open up an immense area for exploring the above mentioned points. Enquiring into woman identity, the article attempts to approach the question from ethnic perspectives, thus our heroes are not just ethnic minorities, but also minority women.
\end{abstract}

Keywords: ethnicity, feminine, identity, East, West, archetype, Yin, Yang, orientalism, woman warrior, colonial

\section{Introduction}

The Masculine Yang of the West meets The Feminine Yin of the East; the substance faces the spirit, the rationality encounters the intuition, the individuality comes across with the collectivism, while the West is engaged in the question of "how", the East deliberates on question "why", one is involved in living at present, the other one looks for infinity and accepts death as a matter of transition. However, both Yin and Yang are enthusiastic about one another, both find each other fascinating, intriguing, and on the other hand alien. Our androgynous heroines, "the suffragist" of Great Britain, Mary Mackenzie and "the Dragon lady" of China, i.e., Chinese-American Maxine, turn out to be aliens in their lifetime, while Mary calls herself "an alien stubborn Ginger Tree" in the Japanese garden, the latter calls herself "The Avenger" or "The Woman Warrior", but both struggle to fit in the culture or society that is exotic for them.

"In the nineteenth and early twentieth century, there was a mosaic of ethnic groups, often living side by side, which were mobilized by different national movements. In the process, ties based on common kinship, ethnicity, neighborhood, religion, language, customs and "mentality," rather than common political institutions and territory, became the basis for nationhood." (18.177)

There are a number of western characters in the literary history and theories who have been amazed by the exotic beauty, attraction and the mystery of Far East. Mostly romantic writers and poets tended to portray Far East through the idealization of rural and natural life. On the other hand, the locals of Far East alongside with their culture and traditions in comparison with the industrial revolution of the West were depicted with striking effects, in a sense, the primitivism of pastoral life and the innocence of locals were the indications of terrestrial utopia in the pens of romantics. While the first wave of orientalism began in the Europe three hundred years ago, the oriental subjects provocatively penetrated into the outstanding European literature through the following centuries, (Voltaire, Montesquieu, G. G. Byron, Lake School Poets, etc.) but the second wave of orientalism boosted in late XIX century and it continued to grow in popularity in the world literature and philosophy. Grigory Chkhartishvili in his article elicits orientalism and the interest to orientalism in this way:

"A distinctive feature of Orientalism as a literary movement and artistic device finds itself in the love of the 
East from a distance; often adoration for the East is fictional, idealized. It appears as a metaphor, as a mirror by which the West attempts to detect its own defects and unsympathetic faces. Not once the East served to Western literature, as an argument, proving the incorrectness of the West." (2)

The author of "The Ginger Tree", Oswald Wynd, was born in Japan in 1913 in the foreigners' quarter of Tokyo. The author himself writes "despite my Scots background, I felt very American and never felt less British than when having to attend those Empire Day celebrations at the Embassy." (1) In his young hood, Wynd travelled to Scotland and would stay there so far, if the First World War wouldn't start and he didn't have to halt his university education. Wynd was captured by Japanese militants and imprisoned due to his dual nationality. O. Wynd after prison promised to never come back to Japan -"I had loved the people when I was in Japan, but I grew to hate them for their brutality, not that I was ever tortured, though I was beaten." (1)

Presumably being as a "lost novel" at the present, "The Ginger Tree", was penned in 1977 bringing to the author high popularity in his life time. "The Ginger Tree" portrays the writer's memories and experiences connected with Far East, both, Japan and China. Oswald Wynd's heroine is a Scottish woman facing a number of hardships and showing great courage to overcome them. Writing from a female perspective for a male author, obviously arises gender identity crisis due to the difficulties in portraying woman feelings or emotions, bringing him to constant antagonistic criticisms. Susan Gubar states that male writers often use literature as a way to create women the way they would like them to be created; women are the "blank page" upon which the male writer writes. (10.2) It is to be presumed that Wynd wrote convincingly as a woman: Mary Mackenzie both in comments on her own life experiences and also in her observations was a realistic and natural feminine. Wynd was perfectly capable of getting inside the female character, writing consistently and honestly. However, the alter ego of Mary Mackenzie (Wynd himself) predominates in some chapters: Firstly, Mary's cold reaction towards being deprived from meeting her daughter, Jane, does not express the sense of natural mothering. Secondly, the British man's imperialistic judgment on political issues outweighs natural feminine. The latter work which will be discussed and analyzed in this article is "The Woman Warrior" by Maxine Hong Kingston. The Asian-American author, Kingston, on the contrary to the British Oswald Wynd is a member of minority literature in the USA and by nationality; she is a Chinese woman in the West. Besides "The Woman Warrior" is considered as one of the first books to herald the explosion of the memoir genre in the late 20th century. Kingston emerged as a controversial writer in the age of increasing cross-cultural interactions, the one who makes efforts to deal with the racial and cultural "other" woman in the western society. Sangeeta Jhajharia and Mamta Beniwal in their thesis work characterizes Asian-Americans for their "immigration and the history of indentured labor underlie a distinctive historical experience." In the same article as for eliciting the consciousness of feminism "white" and "other", they make very reasonable interpretation for feminism in American society:

"For women the experience of feminine sexuality is different according to their distinct ethnic or racial identity: to take the example of religion, Chicanos may be subject to the traditional gender constraints of Catholicism, some Asian American women to those of Oriental Confucianism...." $(7,252)$

The book "The Woman Warrior" is regarded as autobiography of Maxine Hong Kingston and the genre is nonfiction, here the author's literary portray hunts the reader's attention with its mysticism and the reader bewildered to see the difference between the reality and fantasy. "The Woman Warrior" embraces sufficient elements of postmodernism such as metafiction, intertextuality, deconstruction and it breaks all classical canons of literary writing. The author herself challenges the readers with the definition of this memoir, stating like "the voices that I hear inside myself" $(8,178)$. However, there are many controversies among critics dealing with the book being autobiography or nonfiction. Cheang Wai Fong states that Kingston originally intended to publish "The Woman Warrior" as fiction, not as autobiography, the eventual autobiography label was decided upon by her editors, even the narrator admits the novel being "talk story" but not real story. (4.104)

\section{Demolishing Stereotypes of Male-Dominated Society}

Oswald Wynd's writing technique is quite realistic and all the events are depicted with delicate concession, here the novel bears all the elements belonging to Victorian era or early 20th century's social realism. One of the noticeable literary forms connected with the structure of "The Woman Warrior" and "The Ginger Tree" is that both works bear sufficient elements of Identity Plot which is being the narrative form in post-1945 fiction. As these both works came in late 70th just with few years interval and somehow the substantial context of both these literary works are based on woman identity or woman socio-post, human ethnicity or hybridity together with culture clash problems make the plot of both works challenging for literary analysis. Wynd's novel is absolutely precious due to the historical insights of life in Japan and China during the period from the early 1900s to the end of the Second World War. On the other hand, Oswald Wynd as well as Maxine Hong Kingston, 
while portraying their books, was definitely influenced by the ongoing socio-historical movements that started in the 60th and peaked in the 70th both in America and the Europe. Since the 60th and the 70th were the periods of women or ethnic movements globally and in the world literature as well, the writers from different parts of the world and especially post-colonial writers were putting a huge accent on this socio-historical trend. The social movements of the $60^{\text {th }}$ were initiated due to the events supported methodically by the USA government.

"The model of society based on the strong distinction between the masculine and feminine roles was clearly conceived by the government and propagated by the means of communication of the time. The only duty of women was to take care of their families and thus to optimize their femininity. Therefore Betty Friedan, the mother of the modern women's liberation movement evokes the crisis experienced by American women in the 1950's: the crisis of the "ideal women" became a national issue and the need for an identity initiated the questioning of the feminine model." $(11.18,32)$

Friedan's book "Feminine Mystique" managed to change the world as this book re-awakened the feminist movement in the United States. In 1963, the USA and its political and social life were going through rapid reforms, besides another tremendous movement of black Americans for defending their human rights blew away and this gave a huge push to all minorities and also for women actions. Neither Maxine Kingston, nor Oswald Wynd stayed away from the historical trends. They merely illustrated the inspirational effects of then ongoing events in some particular ways. If Kingston approached this question through binary oppositional techniques, simultaneously digging the problems dealing with the ethnicity or gender issues, Wynd's fight was against obsolete feminine and masculine role stereotypes, advocating the migrant literature. Accordingly, Wynd's Great Britain was home to the first feminist movement in the world but Maxine's USA was the country of origin for the most influential and political feminist movement in human history. Obviously, the literary tendency among writers could be classified into two sub-groups:

"one concerned with gender issues, especially the imbalance of power and the attempt to rectify these historical imbalances between women and men, and the other concerned with analysis of race and ethnicity, specifically, the imbalance of power between dominant white groups and peoples of color and the attempt to change the unequal sets of relationships." (12.2)

\section{Identity Plot}

The protagonist woman characters of both these books are fighters and in this agonizing battle, they both choose self-realization, self-development and self-reflexive path. Despite the fact, Mary and Maxine are absolutely different in terms of ethnicity; their destiny of being born as female desperately makes their lifelong fight to look the same. Oswald Wynd's realistic literary technique reiterates the late Victorian writers' literary styles and criticizes the obsolete rules of Victorianism as one had observed in the novels of Thomas Hardy and John Galsworthy. Relatively in this novel the outlaw of the Victorian Era, Mary Mackenzie, is unquestionably "a new woman" in English literature who represents the colonial and imperialistic history of Great Britain. Wynd's depictions of cross-cultural and mixed race relationships are in their well-established reviews. The author's use of letters and diaries makes the storyline of "The Ginger Tree" very effective and catchy. The main heroine, Mary, was able to introduce the characters quite naturally, and develop them through the story. However, the other heroine from "The Woman Warrior" represents the immigration history and racist experiences of American literature. The critic Patricia Blinde refers to "The Woman Warrior" as "a collage of genres" and describes the book as following: "It is at once a novel, an autobiography, a series of essays and poems. But while the work capitalizes on the conventions of various genres, it also evades the limitations of any genre" (8. 81). That is to say, both these works are tale stories, by their female protagonists, while in the novel "The Ginger Tree" Mary Mackenzie travels from Edinburgh to China to marry Richard, Maxine's family illegally left China for the USA in a bid to survive. In the meantime, under the US law Maxine's female family members were not allowed to arrive in the USA, only male members departed for Gold Mountain (the USA) to work for low wages. Mary Mackenzie had a privilege to travel to Far East as an imperialistic British woman and enjoyed the aristocratic advantages of a lady. Maxine pursued a wide range of goals during her life which were not solely restricted to rescuing herself from the miserable life conditions of Chinese migrants in the USA or the circumstances of living as an eastern woman or against the concept of "be only a slave or a wife".

Maxine dreamed to be a woman warrior in the word art and the presented metafictional element, Fa Mu Lan (the Chinese mythical woman warrior who had her village's grievances tattooed on her back) Maxine retells Chinese stories which were hacked to her heart labeled with racial epithets. In fact, Maxine's stories were generated from her life-long struggle against the representatives of racist groups in the USA and also patriarchal Chinese beliefs. One can see a significant difference between Maxine and $\mathrm{Fa} \mathrm{Mu}$ Lan concerning their decision to take vengeance. 
$\mathrm{Fu} \mathrm{Mu}$ Lan silently vowed to vengeance on them all but Maxine is depicted as a woman warrior with blazing eyes engaged in a never-ending struggle.

"The swordswoman and I are not so dissimilar...... What we have in common are the words at our backs. The idioms for revenge are "report a crime" and "report to five families". The reporting is the vengeance - not the beheading, not the gutting, but the words." (9.53)

Here Sangeeta Jhajharia and Mamta Beniwal characterize accordingly "with prose that both unsettled Chinese American sexism and American racism, Kingston is a "word warrior" who battles social and racial injustice." (7, 252)

In "The Ginger Tree" Mary's fight is directed to confirm her autonomous woman personality; this struggle is against worn-out Victorian rules or snobbism that for centuries had deteriorated the lives of dozens especially women with its forgery or hypocrisy. Mary Mackenzie is a mother who lost both of her children because of the existing rules against woman self-identity, she ignored the principles of Victorianism, and she went against conventional rules. She, however, repaid this sin dearly at the cost of losing her children forever. Maxine's aunt "No Name Woman" also repaid her sin at the cost of her own life and her infant, as well. The narrators justify the behavior of "No Name Woman" and Mary in committing adultery sins as the characters apparently fall victim to the shortcomings of the patriarchal societies. Mary Mackenzie, looking for an exciting and happy marriage life, traveled many miles to marry the man she had earlier chosen, i.e., Richard "It seems to me sometimes that I might as well have been a Chinese bride. Since coming here I have only been out of the gate once and that was last Sunday..." (19.60) Mary's honeymoon became so boring that the lonely bride in order to make herself busy had no other choices rather than following her hobby on keeping a dairy. Her interpretation of herself as a "Chinese bride" is strongly associated with "No Name Woman". Maxine's Chinese aunt had a "hurry up wedding" and her husband just like other villagers left for America. The reason of these "hurry up weddings" was assurance for their fidelity that these men will work and send money back to support their parents and the future family. Therefore, this "No Name Woman" is a usual "Chinese bride" and she becomes pregnant while her husband is in Gold Mountain for earning money and sending some part back to China. "No Name Woman" couldn't have been pregnant as her husband was for a long time apart from her "she had almost forgotten what he looked like." (9. 6) Mary Mackenzie feels lonely and unhappy as her husband doesn't show any affection or care to her, they sleep in separate bedrooms even if Mary begs him to stay for a night. She cries alone in her bed, her tears are almost every night wetting her pillow. This solitude and strange world of Far East darkens her honeymoon just she doesn't want to be a "Chinese bride", anymore.

"I do not find being married to Richard what I hoped for in coming to China. I was a fool there, too. Why do we have to make such terrible decisions for our whole lives when we are too young to know what we are doing? The big mistakes are hung around your neck and you have to wear them forever." (19. 95)

Wynd criticizes the limited "woman role" in society, highlights "identity crises" of women; their being pushed for young- age marriages that reduce women to simple and restricted housewives.

Mary saw her "secret seduction" Count Kurihama at the dinner party at Chamonpierres, he was a military attaché at their Legation in China and during the Boxer Troubles he became one of the heroes of the defense. Mary's first impression about Count Kurihama is portrayed as follows- "he should have been a very interesting man to talk to." In "The Woman Warrior" the narrator tries to understand No Name Woman's feelings, her loneliness, her lust for love and passion, she is young and beautiful.

"Such commonplace loveliness, however, was not enough for my aunt. She dreamed of a lover for the fifteen days of New Year's, the time for families to exchange visits, money and food. She plied her secret comb. And sure enough she cursed the year, the family, the village and herself." (9.10)

"No Name Woman" became "the secret evil" of a man in her village, the narrator brings light to this "secret evil" she portrays the women's position in Chinese society and for readers it becomes obvious that "No Name Woman" is nothing more than being a victim "his demand must have surprised, terrified her. She obeyed him: she always did as she was told." (9.13) This "secret evil" was just the part of her woman obedience, there was no difference, and all men in her life whether he is being her father, brother or husband, they just gave orders and she followed all of them as a silent and humble Chinese woman. Mary Mackenzie searches the way out from her loneliness or boredom, she puts her marriage life, her name, and her security at risk, as she looks for an exciting affair. This affair seems so captivating in the presence of Count Kurihama, she grasps every opportunity to be in his company. When Kurihama asks her for a rendezvous, Mary agrees, though she feels like doing something wrong "God forgive me, I went to him. I have no excuse for myself ...I don't know whether this is love. I don't know" (19. 113) As a result of this secret date and as a result of her infidelity, Mary is pregnant and she 
comprehensively understands what she has done and she doesn't have any excuse, she doesn't ask for apology.

"It must be that for all of us there has to be an apology available that we can make to ourselves for anything we do. It doesn't matter so much about an apology to others, pride may block this, but we must have that one for ourselves, to be able to say: "Yes, I did that, but....." If you can't put the "but" after what you did then you are in a sort of way lost. There is no "but" after what you did then you are in a sort of way lost. There is no "but" that I did not know what I was doing when I went up that path to take tea with Kentaro." (19. 117)

Mary sometimes gets upset and links all unpleasant events happening in her life to the sins she had earlier committed "what I have done to Jane and Richard, and to myself, as well as others."(19. 123) Mary leaves Richard's house and she is not allowed to see her daughter anymore even as a nurse, "no court in the world" will help her to have the right to see her own daughter, only her Chinese servant Yao has tears in eyes for his mistress, Yao is a man and we know from "The Woman Warrior" how men are patriarchist and traditional when it comes to the matter of woman infidelity or freedom but why Yao is sorry for her mistress, since he knows the reason for Mary's expelling from the house, yet he is sorry for her and even cries. "I have never expected to see any Chinese man weeping for me."(19. 128) For Yao, Mary is not a woman, she is his mistress, his master who behaved with him so kindly and they smiled together, even without understanding each other quite well because of language barrier, they loved or respected each other as close friends. Yao had a consideration for his identity and for his being a person, human being with individual feelings, soul and character. Since Mary showed this unusual kindness to him, for Yao she is not a woman who betrayed her husband and became pregnant but she is a kind, understanding mistress with unfortunate fate that he feels desperately sorry for. Whilst, in "The Woman Warrior" in Brave Orchid's (the narrator's mother) story the day before the child birth, the villagers raided their house while they all were in white masks and they did so many evil things, actually they did what their traditions dictated them to do. As Brave Orchid tells "the village had also been counting", the villagers were counting the days for this illegitimate child born, they came to remind this and they came to punish the family carrying illegitimate baby and the evil daughter- "punish her at the birth of her baby" (9. 13) The talk story about "No Name Woman" was related by mother Brave Orchid to her daughter Maxine. The daughter Maxine has her own imagination and analyses about her dead aunt "No Name Woman".

"Brave Orchid opens up Maxine's power of imagination and arouses her sensitivity so that the daughter ends up creating an ambiguous world in "The Woman Warrior", where there are several theories for her aunt's misbehavior." (3.5)

The narrator in her own version of the story reveals the man who commanded her aunt to be his "secret evil" and writes "I wonder whether he masked himself when joined the raid on her family". This man wasn't a stranger "because the village housed no strangers". This man wasn't a stranger in the village and when he found out about the pregnancy of Maxine's aunt, he organized the raid on her.

"If my aunt had betrayed the family at a time of large grain yields and peace, when many boys were born, and wings were being built on many houses, perhaps she might have escaped such severe punishment. But the men - hungry, greedy, tired of planting in dry soil—had been forced to leave the village in order to send food-money home" (9.13)

When the village needed money, the mistake of "No Name Woman" just turned out to be a crime. "The villagers punished her for acting as if she could have a private life, secret and apart from them." Her aunt was punished by her family and from that time, she turned to be dead, the family cursed her "you have killed us. Ghost! Dead Ghost! Ghost! You've never been born". (9. 14) This cursed woman was narrator's aunt and she was one of the representatives of majority of victims of Chinese patriarchal society, she was feeling sorry for her, she was feeling anxiety, anger towards harsh reality but the only thing she could do was giving voice to her Dead Aunt, she wasn't able to give name therefore called her "No Name Woman" at least, she wrote memory about her. When the narrator describes the torture of the pregnant woman and her giving birth in a pigsty, the readers mourn for "No Name Woman". "She was one of the stars, a bright dot in blackness, without home, without a companion, in eternal cold and silence." (9.14) "No Name Woman" was also understanding that "no one would give her a family hall name... A child with no descent line would not soften her life but only trail after her, ghost-like begging her to give it purpose".

The child is a girl and this makes the situation even more dreadful "there is some hope of forgiveness for boys" but not for girls, so the mother doesn't have any choice just killing herself and her daughter, she realizes that there is no place for her and for her daughter in this society, they are doomed to tragedy. The narrator's final line for this tragic story becomes more drastic as her mother orders "don't tell anyone you had an aunt. Your father 
does not want to hear her name. She has never been born" (9. 15) She had been a victim, but for her family and for all villagers, she was a misery, she was a "whore", whose name had been erased forever. Mary Mackenzie doesn't think of death, she only thinks of escape from the awkward situation, she doesn't go to Scotland which Richard was to send her to Edinburgh, returning Mama, and Mary knows what expects her in the hometown and even in this situation the freedom is so precious, since Mary thinks of leaving the ship and finding a job, hence it is also not relevant alternative for her during pregnancy, so The Count Kurihama provided Mary with "an escape" and she definitely understands that she must make future for herself. What is the huge difference between these two women with the same situation in Far East? One is a native to Far East who never had any privileges to make her own choices as everything was arranged for her even before she was born. It is so clear if she is a female then she must live the life that was planned to her many centuries before. Mary's situation is different; yet, she was also expelled from her house, society and family, besides she was doomed to loneliness but at least she had the ability or probably an opportunity to choose. Unlike Chinese women, Mary wasn't deprived from the right to choose; besides she had a support from the man who was the father of her child. Nevertheless, in Maxine's Chinese village, the father masks himself and attacks the mother of his own child along with other villagers. When Mary Mackenzie lost her first kid, she was getting ready to deliver her second child. The unplanned pregnancy probably empowered Mary and encouraged her to take up struggle against the women's humiliation. She gave birth to a boy and named him Tomo, this boy is Japanese by birth and Mary is not able to take the child with herself anywhere, she doesn't know how the West would receive the half-Eastern child. The climax of the novel turns up as Mary Mackenzie loses the right to see her son Tomo forever. She is in a dire situation and she feels lost "women have no rights at all in this country?" she screams but her Japanese companion Aiko's (The Baroness who fights for women rights in Japan) response is the unquestionable definition of a woman's tragedy in both eastern and western worlds "No. And not too many in yours, either. You lost your daughter, didn't you?" (19. 176) Indeed, Aiko made to the point remarks as under the British law the divorced Mary Mackenzie was denied from the right to meet her sole daughter because Mary's ex-husband prohibited her from meeting her kid. The British widowed mother for the second time lost the right to raise her kid, a baby boy, as the Japanese law would never allow the British woman bright up the illegitimate child due to his fully Japanese features in appearance. No doubt that being a direct descendant of the well-known Japanese commander, Count Kurihama, played a key role in making the fateful decision on the future relations between the mother and the child.

Western woman meets Eastern world and Mary is harshly criticized over her taboo-breaking character by the two civilizations: both eastern and the native western cultures are against her personality. Mary Mackenzie is a woman rebel; she is an outlaw for both eastern and western societies.

"Not only had the East but also the West puts emphasis on women's "maternity" or "motherhood." In their points of view, the ideal of the good mother should be taught to please her husband. She must abjure the opportunity to contact other men and her sexuality should be lessened or de-sexed. $\{\ldots\}$ They are required to stay at home and their best jobs are as males' sexual servants. $\{\ldots\}$ Men admire Virgin Mary because she is the mother of Jesus. But when they find that Virgin Mary gets the same rights and powers which are even more supreme than God, men decide to dethrone her." (13.6)

In both cultures men feel insecure dealing with "woman power", in both civilizations women tend to be limited to some distinct "role models" as, Maxine mentions up "perhaps women were once so dangerous that they had to have their feet bound." (9.29) Maxine is so frustrated towards the tortures suffered by Chinese women and for sure with this description the narrator even hardens the paradoxes "we could be heroines, swordswomen" little Maxine understands women humiliation as a result of male's fear or insecurity. While being British, having British education or descent contributed huge privileges to Mary Mackenzie in the eastern lands, Chinese women Brave Orchid or Moon Orchid in the West did not enjoy such privileges. Mary Mackenzie wasn't a missionary woman, but she came to China, the city Manchuria in 1903 when she was just eighteen to marry a British army officer posted to Peking and in these lines of the novel the readers just observe her strong will and character. Mary sails from Edinburg to China and she broadens her life experience during the long journey- "It is almost frightening that you can travel in a ship and feel yourself changing" (19. 6) Mary in a letter to her mother expresses her feelings as follows: "Well, I'm having experience now... Good and bad are not as simple as we thought. On this ship I have become five years older" (19. 23) Mary Mackenzie's British nationality somehow brought her good luck, the imperialistic diplomacy of British government for sure generated huge opportunities for its citizens whether being a female or a male.

"During the next three quarters of a century, Britain sent more missionaries overseas than any other country, and by the end of the century, well over half were women. At the beginning missionary women were in small 
numbers in the missionary movement, but by the early 20th century, missionary women there outnumbered their male colleagues by nearly 20 percent."(15.22)

Therefore, British women had that freedom to travel or participate in socio-political events; for sure, these presences had promoted huge privileges for British women. It is an obvious fact that the first woman movement was launched in Great Britain in late $19^{\text {th }}$ century when women found a golden opportunity for education and employment, thus outnumbering men in missionary movement had been a tremendous achievement. Miss Bassett -Hill, a missionary woman, threw her full support behind the helpless Mary Mackenzie as she was expelled from her husband's house, from her own family and even from the British Embassy in China. Mary Mackenzie through establishing emotional ties with Miss Bassett -Hill, or Baroness Sannotera Aiko makes her woman identity distinguished, and grows in maturity. Maxine from "The Woman Warrior" also thrives for gaining experience and she stands against the stereotypes of being a "slave woman", she longs for education and through education achieves freedom "I learned to make my mind large, as the universe is large, so that there is room for paradoxes" (9.29)

\section{Mother-daughter Relationship}

The relationship between mothers and daughters in both works is a comprehensive topic for an analysis.

"The cathexis between mother and daughter-essential, distorted, misused-is the great unwritten story. Probably there is nothing in human nature more resonant with charges than the flow of energy between two biologically alike bodies, one of which has lain in amniotic bliss inside the other, one of which has labored to give birth to the other." (6.200)

In "The Woman Warrior" the relation between the narrator and her mother plays a considerable role, somehow, the mother Brave Orchid turns to be the narrator of the memoir in some chapters. Kingston's work is primarily based on tale stories of her mother. And as a daughter, she is in everlasting competition with her mother "I'm really a Dragon, as she is a Dragon, both of us born in dragon years. I'm practically a first daughter of a first daughter." (9.109) In chapter three named "Shaman", Maxine attempts to find her own identity and creates her new psyche through analyzing her mother Brave Orchid's character. "Understanding the past changes the present and the ever evolving present changes the significance of the past." $(14,179)$ She has been stuck in her childhood and girlhood, Maxine believes that if she manages to sense her mother, she will get rid of ghosts that insistently pull her to be drown in her childhood oceans. As Judith Kegan elicits the mother-daughter relationship

"Discussions of female identity thus inevitably return to the special nature of the mother-daughter bond. The current, rapidly proliferating literature about motherhood stresses that the daughter's identification with and separation from the mother is crucial to the daughter's mature female identity." (5.356)

Conceivably, the author Kingston, as a consequence of exploring the mother archetype, assumes she will once unite with The Queen or The Medial, therefore, this memoir anyhow is considered to be an autobiography, or else Kingston's attempt to deal with her "identity crisis". The narrator Maxine portrays Brave Orchid as an "intelligent, alert, and pretty" woman but she is not sure whether her mother was happy. The narrator makes efforts to elicit all dim moments connected with her mother "I would grow up a wife and a slave, but she taught me the song of the warrior woman, Fa Mu Lan, I would have to grow up a warrior woman" (9. 20) while the episode on the song of woman warrior poses an apparent paradox, Maxine's illustration appears to be mind-blowing. On one hand, Brave Orchid pushes Maxine to be a wife or a slave, and on the other hand, the mother teaches Maxine the song of woman warrior as if the mother's alter ego wishes her daughter to become the woman warrior fighting just like Fa Mu Lan to save her village, which eventually would pave the way for the family to go back home (China).

Kingston highlights the significance of her mother's talk story which apparently was aimed at protecting the kids against possible risks. "She will add nothing unless powered by necessity, a riverbank that guides her life."(9.6) There is no doubt that Maxine, periodically, practices bitter but perceptive irony while portraying her childhood and her interaction or conflict with the mother. Therefore, her mother's talk story has two missions, first: to warn her against villagers and urging them to always keep in mind that she was other woman, the second mission was more global and crucial; it was being alien or among aliens and being under pressure and being able to survive under harsh realities- "whenever she had to warn us about life, my mother told stories that ran like this one, a story to grow up on. She tested our strength to establish realities." (9. 5)

"The Ginger Tree" portrays Mary's mother as a typical representative of Victorian period, the readers get acquainted with mother only through the narrator's description, mother actually doesn't participate in the novel and only memories or speculations about her nature are narrated by Mary. We get introduced with Isabel 
Mackenzie from the preliminary pages of the novel as Mary constantly writes letters about her travel adventures, later about marriage days. In a sense, the reader realizes sharp differences in terms of content in Mary's letters addressing here mother and her own diaries. The hypocrisy existed in the Victorian era quite brilliantly shows itself in the letters of Mary Mackenzie; the letters addressed to her own mother are restricted to some limited descriptions or the statements that only Victorian aristocracy could receive. Otherwise, Mary should expect utterly harsh reaction which could make her fully sorry.

"I knew that I had said things in the letter that I should not have done. ...I appear to her to have suddenly grown hard and worldly...I am a fool to have written to Mama. It is as if I had forgotten, in half a year, what she is really like and how she has always lived..... In future I will always be the dutiful daughter and write to Mama about the weather and what a lovely evening we had at the Italian Legation." (19.95)

Mary's letters to her mother or her own notes are absolutely different from each other, there are two distinct people; the one that her mother knows is the young female representative of Victorian Era. On the other hand, the other Mary who records the diary is "the new woman" of the 20th century. "I have decided right now that I must not send this notebook to Mama as I promised. ...I have found myself wanting to write down things that she must never see." (19. 5) In the beginning of "The Ginger Tree", we feel Mary's sharp criticism and detailed description of every situation that happens to her or she observes. She is aboard the ship in a long journey from Edinburg to China and she starts to change, maybe she starts to grow mature, whatever she feels or thinks differently from usual Mary reminds the name of her mother and her possible reactions towards her daughter's transformation. Even if it is so small change like Mary's decision to avoid wearing the corset because of hot weather and she keeps on writing the things that Isabel Mackenzie would like to read within the letters from her young daughter who travels to Far East for getting married. Mary mentions about her mother when she has her period in her hotel room, she reminisces her mother's strange reaction towards this situation "not only because one must never speak of it but also she dislikes having any sign at all brought to her attention." Mary even became so startled when Mrs. Blair spoke openly to her about this topic.

"I will never forget how frightened I was the first time, which was at school. That was when Margaret Blair helped me and we became such friends. If I ever have a daughter, I will not let her have such a shock. The thought of having daughter is strange." (19.33)

Jitender Singh's particular interpretation due to the above mentioned fact implies convincingly.

"Thus, the dominating circumstances shape the mother-daughter relationship in society. In her attempt to get recognition, the girl child, daughter, protests to be different from the mother. But when she herself attains motherhood, only then the daughter tends to identify herself with the mother" (16. 2)

The readers obviously witness Mary's superficial attitude towards her daughter, and how Mary's lover archetype (the Hetaira) predominates Mother as Isabel Mackenzie's Queen Paradigm overshadows her Mother. Getting valuable experiences from travel, Mary still feels fear of sharing her developing ideas with her mother and repeatedly mentions: "Mama would die if she knew I had put down words like this." (19.38) The reader observes a huge gulf between Mary and her mother even she knows more about their Cook's visions than she knows anything about her mother's thoughts. We feel this gulf again when Mary mentions about her marriage and the difficulties she faces "mama gave me no advice on marriage as from a mother to her daughter and all I can remember is that she once said the honeymoon can be trying time." (19.62) After Mary's infidelity on Richard, the mother never replies to her letters, Mary suffers of the state that she continues to live, she continues writing to her mother but the mother doesn't respond. Although Mary realizes Isabel Mackenzie will never write back, she goes on sending those letters and even "feels released to talk to her on paper" and she imagines her son Tomo writing letters to her from long distance, as well. She cries for her mother and she cries for herself, this situation still remains so painful. The only letter after decades was the Last Will and Testament of Mrs. Isabel Mackenzie delivered to Mary from Edinburgh. Mary again thinks of her being classified as an outcast by her mother, but she again pleads for her and blames herself "if I had tried even just a little harder I might have broken that barrier between us." (19. 271) However, she finds out the huge secret that her mother hid from her, Mrs. Isabel Mackenzie pays dowry to Mary's husband, Richard, for the sake of her granddaughter, Jane Collingsworth. "There was never one word in her letters that would have given me a clue to this situation and she must have gone on paying that money to Jane as a matter of pride" (19. 272) Mary in "The Ginger Tree" compares herself with her mother and she touches upon irresistible ties between them "poor Mama and that dour, stubborn Scotch pride. I suppose there is a lot of this in me, too." (19. 272) Another similar point between these two women is complicated relationship with the mothers. Additionally, both Maxine and Mary draw an obvious analogy with their mothers, this binary opposition obviously highlights mother-daughter relationship and verifies 
their credibility for both, Western and Eastern feminine. While Mary Mackenzie witnesses strong resemblance with her mother in the so-called "stubborn Scotch pride", Maxine sees a close resemblance with her mother concerning "Dragon Woman". Yet Mary had never been forgiven by her mother but Maxine had her lifetime reward from Brave Orchid "I never do call you Oldest Daughter. Have you noticed that? I always tell people, "This is my Biggest Daughter"” (9.102)

\section{Self-identity Recognition versus Cultural Clash}

Hence, the one comes across with a crucial moment dealing with biculturalism, hybridity and ethnicity. In fact, Chinese Maxine struggles to become Americanized; meanwhile, in confusion she makes efforts to forge her own identity wishing to meet the two extremes of Eastern and Western cultures. Noticeably, Mary Mackenzie never feels this necessity, and she never attempts to unite these two civilizations. Mary views Far East as an opportunity to her woman autonomy as she understands that for women to have full identity and freedom, they need more than ever economic independence. Wynd very delicately accents the topic of economic independence as Mary tries her strength on fashion and builds up her own business. The Warrior Maxine realizes this economic independence, as well "does the women's work; then do more work, which will come ours too. No husband of mine will say, "I could have been a drummer, but I had to think about the wife and kids"” (9. 48) Maxine clearly perceives that any freedom would never be achieved, if there were no sacrifices. She has to sacrifice her young hood and beauty for the sake of her job, her only support is her job or else she knows exactly that the job is her "only land".

"Mrs. Brinkhill told me to expect to see great misery in China and said that I would get used to it." Mary deliberates the life of poor people in China and their anger towards foreigners living in a hotel like she stays "but these poor people here can look across at buildings like my hotel, all lit up with gaiety and high living." Mary admits of having poor people in Edinburg as well but her mother "would never allow her to visit slum dwellers", while she compares poor people of China to poor ones living in Edinburg, she comments "still, I cannot believe that the poor in Scotland are anything like as poor as these Chinese on boats." (19.32) This misery is familiar to Maxine whether it is observed in her mother's tale stories or in her own childhood, the absolute truth is that Maxine's family and her villagers were constantly struggling to survive whether being in their homeland or in alien world. When Mary notes "it is great country for ghosts; everything is haunted, including trees." (19. 153) The same attitude shows up in "The Woman Warrior" by Maxine or almost from all her relatives or villagers, for her mother Brave Orchid America is "a ghost country", all alien people or things seem ghosts for Brave Orchid or Moon Orchid. However, when Maxine grows older and visits her parents' house, she confesses she doesn't feel good in parents' house, when she is away from this house she doesn't get sick, she doesn't have problems with breathing, she doesn't have headache, and the most important, she doesn't have to lock her room door, she doesn't see any ghosts or their movements. Mary doesn't notice the "ghosts" that Eastern people see continuously, however, Maxine doesn't want to detect those "ghost" being American or being Western seems practical or somehow easier. "Maxine presents Chinese culture as a conglomeration of controversial diversity. She considers Chinese culture as superstitious, inaccurate, barbarous, and aboriginal." (13. 5) Therefore, the "ghost" topic steadily startles the western woman, Mary feels uneasy when she encounters Kurihama's belief on ghost existence

"I have never heard of a soldier sending messages to the spirits of those killed under his command asking to be forgiven for his errors as their leader. It seemed wild and strange to me, but it also suggested a kind of brotherhood that was utterly different from way in which I have heard Richard speak of the men under him when he was with the regiment." (19.112)

Still, Mary feels admiration to Kurihama's responsibility over his soldiers; she sees the feeling of Japanese male as a sign of high morality, in comparison to her British husband. Moreover, Count Kurihama elicits the cause of usual earthquakes in Japan and he comments that "Japan was mounted on the back of a huge dragon which was subject to uneasy dreams." (19. 83) While Mary linked the usual earthquakes to volcanic activities, Count Kurihama's reply just sounded like a joke but Kurihama was quite serious in his remarks. While Kingston's "No Name Woman" was introduced as the "secret evil" of the village man, Mary Mackenzie appears to be the "secret seduction" of Count Kurihama, "he would never have issued such an invitation to a Japanese wife. Perhaps, they think we are all loose women at heart" (19.112), as Count Kurihama invites Mary to tea. The female morals are interrogated then shaped by male supremacy, Mary is considered as a "loose woman" by her western family or society and the same woman is considered as a "loose woman" by alien eastern society, as well. Therefore, in either Maxine's, or Mary's societies, if women do not obey men's orders, they are seriously punished. Mary's assumption certainly arises from culture clashes, comparing her situation with the Asian women who retain no civil rights; Mary takes the invitation as a terrible insult as the man supremacy and patriarchal despotism make 
her to feel the intense sense of humiliation.

\section{Conclusion}

We might sum up that both authors are engaged in the problem of "Other" woman identity, while Mary is not able to find peace without belonging to a certain state, Maxine goes further and brings about a new approach belonging to the planet.

The last chapter of "The Ginger Tree" portrays Mary's compulsory leave of Japan, Wynd gives a sign to the imperialistic nature of a British woman "in a war that looks like tearing the world apart I am making money and hunting for a house. I ought to feel guilty..." (19. 243) Despite holding a British passport, she feels stateless; physically Mary doesn't have any boundaries to go back to Britain, all the obstacles preventing her from going back had already vanished but she still feels stateless, in her adulthood, she is lonely, childless and homeless, even she succeeded in her economic freedom, she doesn't feel happy. Mary farewelled his Asian-born son to the Second World War, perhaps he won't come back from this war, "he didn't believe that Japan could win or that he would live to see the peace".

The author highlights the British mother and Asian-born son never meet each other, as Mary doesn't fit in Japanese garden, Tomo doesn't fit in British garden, either. As Rudyard Kipling wrote, "Oh, East is East, and West is West, and never the twain shall meet". If Wynd doesn't believe in the assimilation of the eastern and western civilizations, Maxine combines in her identity the part East and the part West, she is the predecessor of Tomo "Maxine escapes from the social structure of the East and the West. She builds up her feminine kingdom by herself." (13. 7) Mary feels stateless, she is old and she isn't able to strive for her woman happiness, and loneliness is her lifetime companion, for all that Maxine is still young and full of hope or dreams and she is so right in her statement directed to her mother that "we belong to the planet now, Mama. Does it make sense to you that if we're no longer attached to one piece of land, we belong to the planet?" (9.107)

\section{Reference}

Asian-American Literary “Authenticity”: Frank Chin's 1991 Criticism of Maxine Hong Kingston in 1975. (2006) Retrieved http://www.dartmouth.edu/ hist32/History/S08\%20-\%20Maxine\%20Hong\%20Kingston\%20-\%20Frank\%2 0Chin\%20Debate.htm

Chan, L. S. A. (2003). Talk Stories of The Woman Warrior. Retrieved from https://www.researchgate.net/...Woman_Warrior/.../0fcfd4fff7cbf1a97b000000

Chkhartishvili, G. (1996). Just there is no East and West. On the new androgynies in world literature. Иностраннаялитература. Retrieved from http://magazines.russ.ru/inostran/1996/9/vostoc_z.html

Fong, C. W. (2004). From Culturally Confused "I" to bicultural "We": Maxine Hong Kingston's Trilogy. Journal of General Studies. Retrieved from http://b020.hv.knu.edu.tw/ezfiles/20/1020/img/124/155505706.pdf

Gardiner, J. K. (1981). On Female Identity and Writing by Women. Critical Inquiry. https://doi.org/10.1086/448158

Hirsch, M. (1981). Mothers and Daughters. Chicago: The University of Chicago Press. https://doi.org/10.1086/493870

Jhajharia, S., \& Beniwal, M. (2012). Braving out in the Face of Constraints: The Woman Warrior. International Journal of Social Science and Humanity. Retrieved from http://www.ijssh.org/papers/105-CH238.pdf

Job, J. (2008-2009). The Woman Warrior: A Question of Genre. Journal of the CAS Writing Program. Retrieved from https://www.bu.edu/writingprogram/files/2010/02/wrjournallissue.pdf

Kingston, H. M. (11976). The Woman Warrior. New York, NY: Vintage Books

Lamb, V. M. (2011). The 1950's and the 1960's and the American Woman: the transition from the "housewife" to the feminist (Master's thesis, University of South Toulon-Var, UFR Letters and Humanities, France). Retrieved from https://dumas.ccsd.cnrs.fr/dumas-00680821

Lange, C. (2008). Men and Women Writing Women: The Female Perspective and Feminism in U.S. Novels and African Novels in French by Male and Female Authors. UW-L Journal of Undergraduate Research XI. Retrieved from file://C:/Users/User/Downloads/11895380.pdf

Lim, S. G. L. (1993). Feminist and Ethnic Literary Theories in Asian American Literature. Feminist Studies. https://doi.org/10.2307/3178101 
Lu, V. J. L. (2005). Body Discourse: Woman Warrior and the Creation of Woman Subjectivity. Journal of Humanities and Social Sciences. Retrieved from http://ir.hust.edu.tw/bitstream/310993100/385/1/05-1

Rabinowitz, P. (1998). Eccentric Memories: A Conversation with Maxine Hong Kingston. In P. Skenazy, \& T. Martin (Eds.), Conversations with Maxine Hong Kingston (pp. 67-75). University Press of Mississippi. Retrieved from http://ayersamazingwiki.wikispaces.com/file/view/Eccentric\%20Memories\%20-\%20A\%20Conversation\%2 0with\%20Maxine\%20Hong\%20Kingston.pdf

Seton, R. (2013). Western Daughters in Eastern Lands: British Missionary Women in Asia. Santa Barbara, California: An Imprint of ABC- CLIO, LLC

Singh, J. (2012). Deconstructing Mother-Daughter Relationship: A Study of Manju Kapur's Difficult Daughters. The Criterion: An International Journal in English. Retrieved from $\mathrm{http}: / /$ www.the-criterion.com/V3/n1/Singh.pdf

The Herald. (1989). Tracing the roots of The Ginger Tree. Retrieved from http://www.heraldscotland.com/news/11969479.Tracing_the_roots_of_The_Ginger_Tree/

Wolczuk, K., \& Yemelianova, G. (2008) When the West Meets the East: Exploring Ethnic Diversity in Eastern Europe. Nationalities Papers. http://dx.doi.org/10.1080/00905990801934173

Wynd, O. (1991). The Ginger Tree. New York, NY: Harper and Row

\section{Copyrights}

Copyright for this article is retained by the author(s), with first publication rights granted to the journal.

This is an open-access article distributed under the terms and conditions of the Creative Commons Attribution license (http://creativecommons.org/licenses/by/4.0/). 